\title{
ATmega328P mikrokontroller vezérelt felügyeleti oktatási modul
}

\author{
Karalyos Béla \\ Mérnökinformatikus \\ Debreceni Egyetem, Informatikai \\ Kar \\ Debrecen, Magyarország \\ karalyosbela@gmail.com
}

\author{
Beatrix Papp \\ London South Bank \\ University \\ School of Law and Social \\ Sciences, \\ London, United Kingdom \\ pappb@1sbu.ac.uk
}

\author{
Erdei Timotei István \\ Mechatronikai Tanszék \\ Debreceni Egyetem, Müszaki Kar \\ Debrecen, Magyarország \\ timoteierdei@eng.unideb.hu
}

\begin{abstract}
Absztrakt- Az Arduino mikrokontrollerek megjelenésével komoly lehetőségek nyíltak meg mind a kezdő mind a haladó réteg számára. Ezek a mikrokontrollerek Open-Source hardware-re támaszkodnak, így bárki tud benne fejleszteni, programozni különböző elektronikai eszközöket vezérelni/ adatot lekérni. A projektben egy a Debreceni Egyetem részére készített biztonságtechnikai oktatási modul került megtervezésre és megépítésre, mely teljes egészében flexbilis, újraprogramozható és bővíthető, valamint különféle vezérlések és algoritmusok tesztelésére is alkalmas.
\end{abstract}

Kulcsszavak-Arduino; Arduino UNO; kódzár, Belépörendszer, mikrokontroller

\section{BEVEZETÖ}

A vagyonvédelmi rendszerek mindig is sarkalatos pontjai voltak a fejlesztések/kutatásoknak, hiszen mindenki a 100\% os védelem elérésére törekszik.

Régebben egyszerübb zárszerkezetek, például tolózárak, lakatok voltak, amik elengedhetetlen részét képezték egy háztartásnak. Aztán egyre jobb zárszerkezetek, a mechanikus zárak léptek helyükre. Viszont ebben a gyorsan fejlődő világban egyre elterjedtebbek lettek az elektronikus zárak, amelyek praktikusabbak, mint a mechanikus társaik.

Kényelmesebbek, mivel nem kell magunkkal kulcsot vinnünk, így megelőzhetjük azt, hogy elhagyjuk azt ezzel kizárva magunkat otthonunkból. Manapság már nem csak a bejárati ajtót lehet védeni ezzel a módszerrel, hanem akár a bejárati kaput, szobánkat is. A kutatás/fejlesztésnek a Debreceni Egyetem adott otthont [12].

\section{TERVEZÉSI SZEMPONTOK}

Az oktatási modul megépítése előtt több szempontot kellett figyelembe venni. A legelső és legfontosabb, hogy a rendszer mindig áram alatt legyen, így megakadályozható az, hogy lemerüljön a készüléket árammal ellátó külső energiaforrás. A fontos szempontok között volt még flexibilitás a további fejlesztési lehetőségek miatt. Megjelenés szempontjából pedig, hogy az alkatrészeket egy külön ennek az eszköznek tokozást kapjon a külső fizikai sérülések ellen. Fontos volt még, hogy a készülék használója visszajelzést kapjon arról, hogy épp milyen müveletet hajt végre, amennyiben hibás zárkód bevitelére kerül sor egyértelmüen eldönthető $\mathrm{s}$ felismerhető legyen.

\section{A RENDSZER FELÉPÍTÉSE}

A rendszer központi eleme, az Arduino Uno mikrokontroller. Ez a típusú mikrokontroller 8 bites, a processzor egysége egy $16 \mathrm{MHz}$-es ATmega328p. Az input/output lábainak száma 14 darab, és 32kilobyte flash memóriája van. Logikai feszültség szintje $5 \mathrm{~V}$ [1].

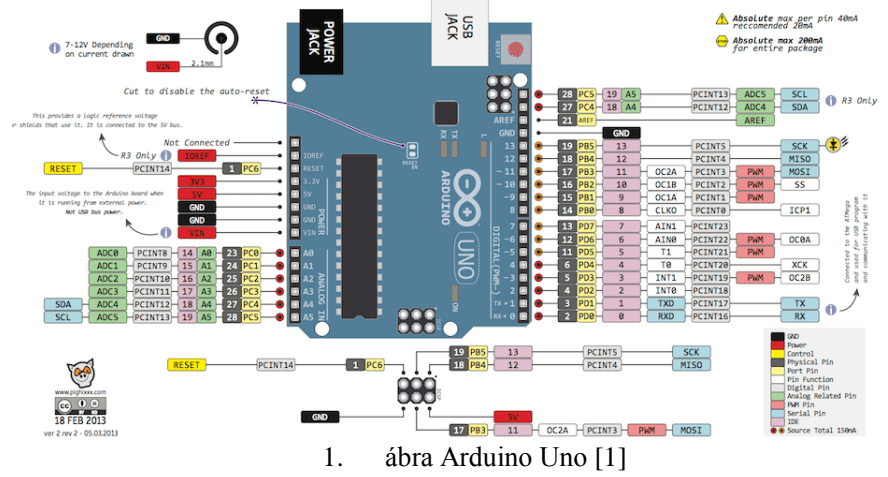

A processzor UART (Aszinkron soros kommunikáció) kommunikációra is képes a digitális 0 és 1 -es lábain keresztül. A mikrokontrollerhez kódot írni a hozzá ingyenesen letölthető Arduino IDE [2] [9] szoftverén tudunk, amely kereszt platformos JAVA nyelvet alkalmaz. A számítógéphez USB-n keresztül tudjuk csatlakoztatni az eszközt, majd, ha kész a kódunk, rá tudjuk tölteni az eszközre.

A megtervezett és kivitelezett rendszer másik fó hardware eleme a nyomógomb panel (2 ábra). A panel egy 4x3-as mátrix, amin 1-től 9-ig van a számozás, és két speciális karaktere van a \# és a * karakter. Ezeket a nyomógombos paneleket nagyon sok helyen használják világszerte, legfóképp ajtóknál. A nyomógomb panelből 7 darab kábel kapcsolódik az Arduino 2-9 lábaiba. Vannak oszlop és sor pinek, amelyek 
segítenek meghatározni, hogy melyik gomb lett lenyomva a panelen.

Az oktatási modúlban indikátor LEDek is beépítésre kerültek, ezek jeleznek vissza a készüléket éppen használó félnek. Összesen három darab indikátor LED van, két LED a helyes (zöld), illetve helytelen (piros) belépő kód beviteléröl ad visszajelzést, valamint arról is, ha egy gomb megnyomásra kerül. A harmadik LED funkciója, hogy jelzi, hogyha áram alatt a rendszer. Az áram ellátásáról egy kapcsoló gondoskodik, amivel be, illetve ki tudjuk kapcsolni az eszközt. Helyt kapott továbbá még egy „buzzer”, azaz berregő is, ami hang alapú visszajelzést ad.

A másik fontos komponense a rendszernek a szervomotor, ami a tolózár vezérléséért felel, ez nyitja zárja azt.

A motorok típusát tekintve, MG996R [3] szervók kerültek alkalmazásra.

Paraméterek:

- Méretek: 40.7x19.7x42.9 (mm)

- Sebesség: (6.0V):0.14sec/60 degrees

- Nyomtaték: $(6.0 \mathrm{~V}):(11 \mathrm{~kg} / \mathrm{cm})$

- Hömérséklet tartomány: -30 to +60

- Feszültés tartomány: $4.8 \mathrm{~V}-7.2 \mathrm{~V}$

- Súly: $55 \mathrm{~g}[6]$.

A oktatási modul áramköre az ingyenesen letölthető Fritzrig nevü programmal került megtervezésre (lásd 2. ábra).

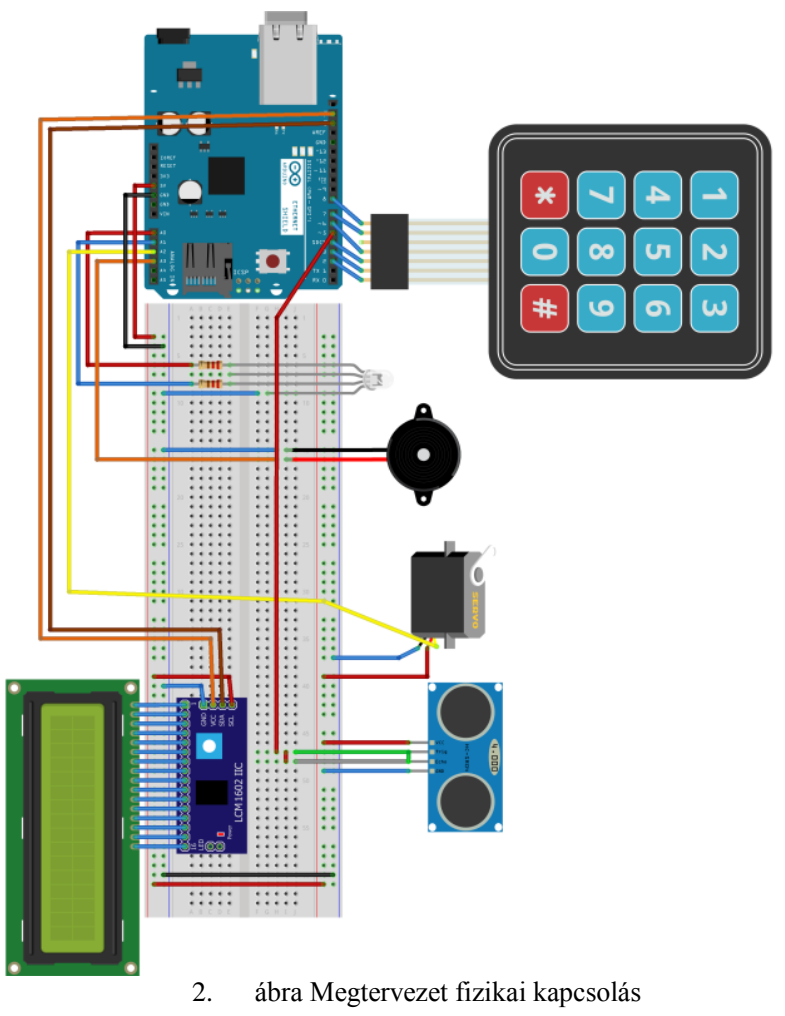

A zár nyitásáról egy ultrahangos szenzor gondoskodik, ami ha egy adott érték alá esik a szenzor által mért táv akkor nyílik a zár szerkezet.
Az oktatási modul kapott még egy az LCD kijelzőt [4], ami 2*16-os típusú, ez I2C-n keresztül kommunikál az Arduino UNO - val. A tápellátásról egy 9V-os 1A-es [5] töltő gondoskodik, így mindig áram alatt van a rendszer, szünetmentes tápegység nem került alkalmazásra, mivel oktatási célokat szolgál az eszköz.

\section{A RENDSZER MÜKÖDÉSE}

Az oktatási modult használónak be kell ütnie egy kódot, amelyet egy Java-ban megírt szoftverrel vihetünk be, egy erre a célra kialakított adatbázisba (lásd később), ahol maga a kód és a hozzá tartozó neve van megadva, és egy dátum mező is amely majd a belépés dátumát fogja eltárolni. Mihelyst beütésre került az általunk beállított 6 számjegyből álló kód, a rendszer lekérdezi az SQL adatbázisból, hogy létezik-e ilyen belépési sorszám, ha igen akkor kiíródik az LCD-re az „Üdvözöljük” felírat alatta az éppen belépő nevével, amelyet az SQL adatbázis ad vissza az arduinonak. Mivel az eszköz lehetőséget biztosít arra, hogy egy adott személyhez lehessen beléptető kódot hozzárendelni. Továbbá a belépést követően beíródik a táblázatba a belépés dátuma másodpercre pontosan. A sikeres belépés közben, amíg az LCD-re kiíródik az "üdvözlő információ, egy zöld led és a berregő is visszajelzést ad.

Miután kinyílt a zár 20 másodpercre marad nyitva, ezután újra aktiválódik és bezáródik. Ha valaki ki akar menni az épületből egy ultrahangos távolságmérő szenzor gondoskodik róla, hogy ha a kilincsre (jelenesetben a tolózár fölé) teszi valaki a kezét akkor egyből nyíljon ki a zár. Ha valaki eltéveszti a kódod, vagy épp nincs kódja és mégis megpróbál belépni, egy hibaüzenetet kap az LCD-n miszerint „Nincs megfelelő kódja, belépés megtagadva”, indikátorokként LED -ként itt a piros LED van jelen és a berregő.

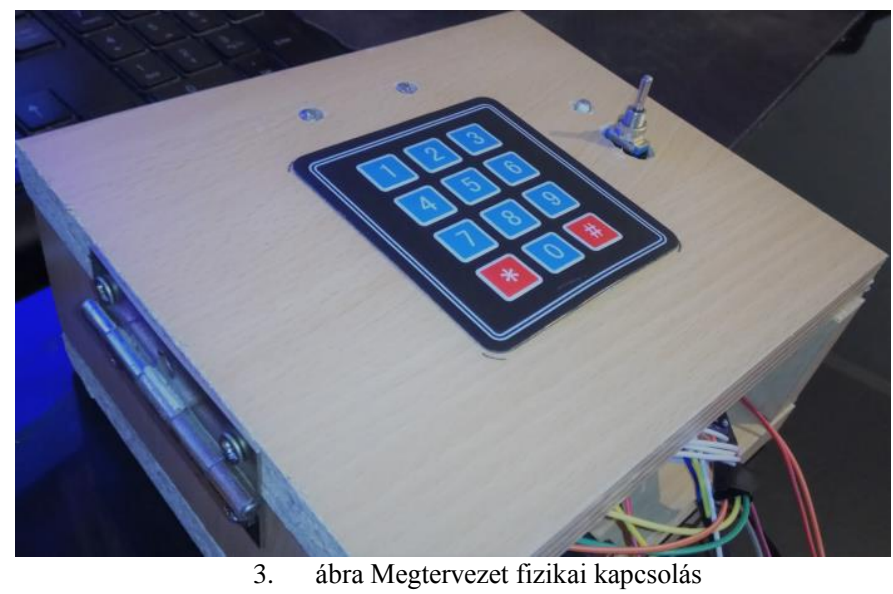

Kivitelezés tekintetében a mechanikai sérülés elkerülése érdekében egy $35 \mathrm{~cm}$ x $35 \mathrm{~cm}$ x $25 \mathrm{~cm}$ fadobozban kerültek elhelyezésre az elektronikai elemek, ahogy az a 3. ábrán is látható. Mivel oktatási eszközként lett megalkotva, így a vezérlések tesztelése végett külön csatlakozási lehetőség lett hagyva az Arduino UNO számára, ezáltal bárki tesztelheti saját biztonság technikai kódját, vagy kiegészítheti a már meglévőt. 
Továbbá IoT [10] szempontokat figyelembe véve egy Ethernet shield -el [11] is kiegészítésre került, a fentebb vázolt kapcsolás, ezzel lehetőséget biztosítva a hálózati kommunikációra (adatelérés/küldés).

\section{NYÍLVÁNTARTÁSI RENDSZER MÜKÖDÉSE}

Az előző pontban említett Java [8] szoftver megírása a Netbeans IDE [7] fejlesztő környezetben íródott meg. Maga a felület funkció orientált GUI-t kapott, hogy csak a fontos dolgok legyenek megtalálhatóak rajta.

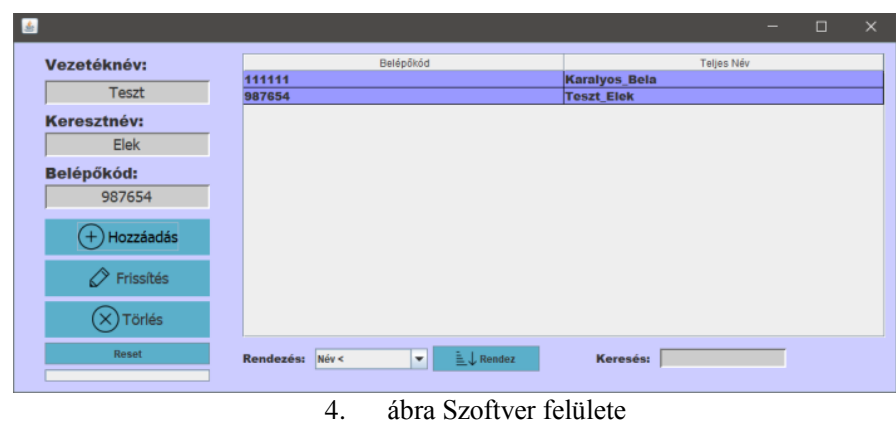

A program kezelője tud felhasználókat hozzáadni, törölni, és frissíteni. Ha hozzáadni akar, be kell írnia a vezeték, illetve keresztnevet, és ehhez a felhasználóhoz kívánt belépőkódot, ami a hozzáadás gomb benyomása után már aktivizálódik és a rendszerrel használható. Ha nem tölti ki a megfelelő mezőket, illetve a belépőkód nem csupa számból áll, hibaüzenetet kap és a hozzáadás sikertelen lesz. Frissítésnél tudja frissíteni a nevet, illetve a kódot. Törlésnél pedig kitörölni az adott felhasználót.

A program táblázata mutatja meg, kik vannak felvéve az adatbázisba, tudjuk rendezni név szerint csökkenő, illetve növekvő sorrendbe, illetve a keresést is tudjuk használni, ami azonnal szüri név szerint a beírt betük, szavak szerint a tábla tartalmát.

Az adatbázis alapjául, ami az információ tárolására szolgál, a Mysql workbench alatt készült el, ingyenesen letölthető és szabadon felhasználható. Ebben a környezetben jött létre a végleges adatbázis, amely a felhasználókat tárolja el, létre kellett hozni egy sémát, majd ebben egy táblát. A három mező, amit a program tábla készítőjében létre kellett hozni, a kód, ez elsődleges kulcsként müködik, hisz két embernek ugyanaz a kód nem lehetséges. A második mező a teljes név, ennek révén lehetséges a felhasználó nevének tárolása, és egy dátum mező, ami a következő alakban tárol: „év-hónap-nap” óra:perc:másodperc. Az fentebb felsorolt táblákat jeleníti meg a Java szoftver.

Egy kiegészítés is elkészítésre került mégpedig, hogy a nyilvántartássorán felvett személyek adati, online formában is lekérdezhetőek legyenek. Így, lehetőség nyílik távolról ellenőrizni a belépők számát, és a távozások idejét. A táblázat automatikusan frissül, érkezés/távozás függvényében.

A kifejlesztett rendszer azért is előnyös oktatási célra többek között, mivel, lehetőségünk van virtuális szerveren is futtatni, ami jelen esetben az Xampp segítségével valósul meg, ezen belül is pedig az Apatche szerverrel.

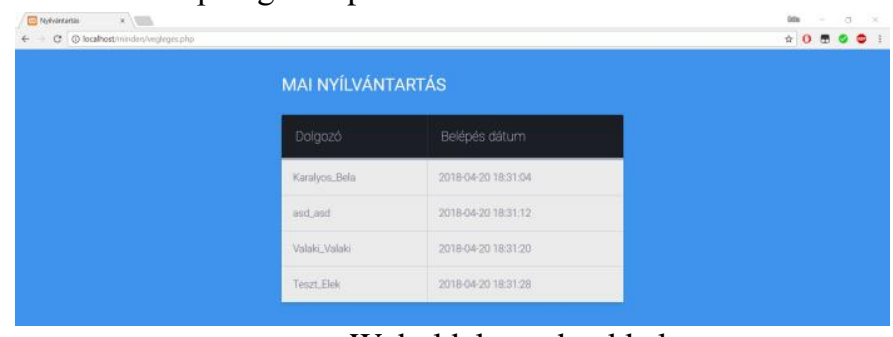

5. Weboldal az adatokkal

Mivel az Arduino-ból közvetlen a Java-ba komplikált az adatátvitelt intézni, ezért kellett egy köztes kommunikáció, így ez Php és Mysql segítségével valósult meg.

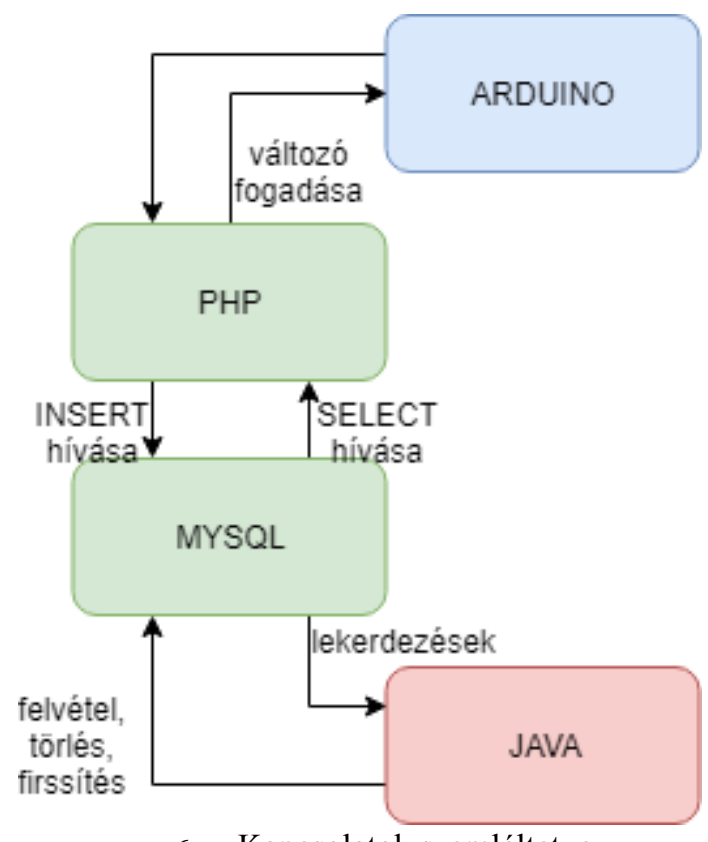

6. Kapcsolatok szemléltetve

Az Arduino meghív egy Php oldalt, amin az adott lekérdezés van, ez a lekérdezés teljesül, majd visszaadja az adott értéket, amit lekérdeztünk. Ezáltal lehetséges az adott kódot megvizsgálni, hogy létezik-e az adatbázisban.

\section{VI. ÖSSZEGZÉS}

A projektben az ATmega328P mikrokontroller alapú vezérelt felügyeleti oktatási modul elkészült. A rendszer flexibilis, tetszőlegesen továbbbővíthető, alkalmas, megírt programok tesztelésére. A modul maga könnyen szállítható és beléptető rendszer adatai a müködés során online lekérdezhetőek.

\section{KÖSZÖNETNYÍLVÁNÍTÁS}

A publikáció elkészítését az EFOP-3.6.1-16-2016-00022 számú projekt támogatta. A projekt az Európai Unió támogatásával, az Európai Szociális Alap társfinanszírozásával valósult meg. 


\section{HIVATKOZÁSOK}

[1] Arduino Uno, (2018, 04 20). [Online]. Avalable: https://www.robotistan.com/arduino-uno-r3-clone-with-usb-cable-usbchip-ch340

[2] RFID egység (2018.04.20). [Online]. Available: https://www.robomart.com/buy-rc522-rfid-reader-writer-arduinocompatible-online-indi

[3] MG996R-55g Gear-Servo-Motor (2017.12.09). [Online]. Available: https://servodatabase.com/servo/towerpro/mg996r

[4] 1602 Blue LCD Module HD44780 16x2 Displays Characters, White Backlight (2018.04.20). Available: https://www.buydisplay.com/default/1602-blue-lcd-module-hd4478016x2-displays-characters-white-backlight
[5] 9V DC Power Supply (2018.04.20). [Online]. Available: https://www.walmart.com/c/kp/9v-dc-power-supply

[6] JAVA (2018.04.20). [Online]. Available: https://www.java.com/en/

[7] NetBEANS (2018.04.20). [Online]. Available: https://netbeans.org/

[8] Mysql workbench (2018.04.20). [Online]. Available: https://www.mysql.com/products/workbench/

[9] Arduino IDE (2018.04.20). [Online]. Available: https://www.arduino.cc/

[10] IoT (2018.04.20). [Online]. Available: https://www.invitech.hu/iot

[11] Ethernet Shield (2018.04.20). [Online]. Available: https://www.arduino.cc/en/Guide/ArduinoEthernetShield

[12] Zs. Molnár, T. I. Erdei, N. C. Obinna, G. Husi, „A novel design of an air-cushion vehicle and its implementation," IMTU Oradea Proceedings of the Annual Seesion of Scientific Papers May 25th - May 27th

2017. 